\title{
Pedagogic Competence, Work Motivation, and Job Satisfaction (Factors Influence Lecturer Performance)
}

\author{
Misdalina $^{1}$, Moch. Asmawi ${ }^{2}$, Bedjo Sujanto ${ }^{3}$ \\ \{misda_lina68@ymail.com ${ }^{1}$, asmawi.moch@yahoo.co.id ${ }^{2}$, bedjo1951@ gmail.com $\left.{ }^{3}\right\}$ \\ Universitas PGRI Palembang, Indonesia ${ }^{1}$ \\ Universitas Negeri Jakarta, Indonesia ${ }^{23}$
}

\begin{abstract}
Factors that influence the performance of lecturers include the organizational behaviour and individual mechanisms. Pedagogic competence is an aspect of organizational behaviour, while work motivation and job satisfaction represent a part of the individual mechanism. Among the three variables, which one needs to be considered first to improve the performance of lecturers? Data from the pedagogic competence test, work motivation questionnaire and job satisfaction from 172 lecturers of the Universitas Persatuan Guru Republik Indonesia, Palembang were analysed using descriptive statistics, t-test and path analysis. The results showed that there was influence of pedagogic competence, work motivation, and job satisfaction on the performance of lecturers. Factors that need to be considered first as intervening variables are work motivation and job satisfaction and further needs to be improved is pedagogic competence.
\end{abstract}

Keywords: Performance, pedagogic competence, work motivation, job satisfaction

\section{Introduction}

Lecturer performance is one of the vital parts in assessing the accreditation of a study program and college. A lecturer is not only expected to perform obligations in the field of education, but also in the fields of research, community service and supporting activities. The current digital era can be utilised by lecturers to improve their performance. This era can be used for the disruption of mathematics learning, which makes learning difficult and frightening mathematics more fun [1].

Lecturers have a small numbers of certificates [2], and their performance is not maximal. Therefore, examining the factors that influence their performance is very essential. These factors can be categorised into organizational behaviour and individual mechanisms [3]. Organizational behaviour comprises of individual characteristics, group mechanisms, and organizational mechanisms. The individual mechanism on the other hand comprises of job satisfaction, stress, motivation, trust, justice, and ethics as well as learning and decision makers,

Performance is related to work that is a product of an activity, which is carried out in accordance with a predetermined time based on the reference activities specified, and the measurements that have been set [4]. Pedagogic competency is the ability to manage learning, and this includes understanding the students, designing and implementing learning, evaluating learning outcomes, and developing students to actualize their various potentials [5]. Vroom's expectation theory is of the assumption that people are motivated to behave in a certain way 
which gives rise to the desired combination of results, meanwhile job satisfaction is an effective or emotional response to various aspects of one's [6].

Results obtained in previous studies indicated that leadership positively influences nurse structural empowerment, which ultimately increases job satisfaction and performance [7]. The results showed pedagogic knowledge to positively correlate with the institution's motivation [8]. There is a direct influence of pedagogical competence and work motivation on the performance of lecturers [2]. Also, business competencies positively influence job satisfaction [9]. The purpose of this study is to provide an overview of the factors that influence the performance of lecturers.

\section{Methodology}

A survey method was employed in this study. The population was 301 lecturers of Universitas Persatuan Guru Republik Indonesia (PGRI) Palembang. The research sample was determined using the proportional random sampling technique totalling 172 lecturers. Data was then collected through test and questionnaire techniques using Likert scale. Before the instrument was distributed to the study sample, it was first tested. The trial results depicted the instruments to be valid and reliable. Then the data was analysed using descriptive statistics, $\mathrm{t}$ test, and path analysis. Complete data sets of this reseach including raw data and data analysis can be access in osf.io/7ja2q/ [10]

\section{Results and Discussion}

Based on the results of the processed data as seen in table 1, there is a positive influence of pedagogic competence, work motivation, and job satisfaction on the performance of lecturers.

Table 1. The Results of t-test and Path Coefficient

\begin{tabular}{llccccc}
\hline \multirow{2}{*}{ Model } & \multicolumn{2}{l}{$\begin{array}{l}\text { Unstandardized } \\
\text { Coefficients }\end{array}$} & \multicolumn{2}{l}{$\begin{array}{l}\text { Standardized } \\
\text { Coefficients }\end{array}$} & \multirow{2}{*}{ T } & \multirow{2}{*}{ Sig. } \\
\cline { 2 - 4 } & B & Std. Error & Beta & & \\
\hline 1 & (Constant) & 39.739 & 6.826 & & 5.822 & 0.000 \\
& Pedagogic Competence (X1) & 0.211 & 0.067 & 0.239 & 3.171 & 0.002 \\
& Work Motivation (X2) & 0.281 & 0.086 & 0.267 & 3.251 & 0.001 \\
& Job Satisfaction (X3) & 0.261 & 0.087 & 0.264 & 3.020 & 0.003 \\
\hline
\end{tabular}

a. Dependent Variable: Performance of lecturers (Y)

There is an influence of pedagogic competence, work motivation, and job satisfaction on the performance of lecturers. Comprehensively, there is a significant effect of pedagogic competence on performance (0.002), and direct effect of 0.239 . Furthermore, there is a significant effect of work motivation on performance (0.001), and a direct effect of 0.267 . Then there is a direct effect of job satisfaction significantly on performance (0.003), and the effect of 0.264. The direct influence of work motivation on performance is greater than that of 
pedagogical competence and job satisfaction. This is in accordance with the results of the data calculation of the average score in the three variables. In the scores of factors that influence performance, work motivation is included in the highest indicator compared to job satisfaction and pedagogical competence. This research also supports the motion that work motivation is the first factor to be considered before others [11]. And competence without motivation has no effect on performance [12]. However, performance does not stand alone. Despite having high motivation, there are employees lacking good performance due to the fact that they do not have the required ability or skills [13].

Table 2 shows the results of the research indicators of pedagogic competence.

Table 2. Average Performance Indicator Scores

\begin{tabular}{lll}
\hline Indicators & Average & Percentage \\
\hline Education And Teaching & 4,58 & 28,6 \\
Research and Development of Scientific Writing & 3,98 & 24,85 \\
Community Services & 4,06 & 25,38 \\
Suppporting Activities & 3,39 & 21,16 \\
\hline
\end{tabular}

The average indicator of lecturer performance is in the good category, the highest is the field of education and teaching while the lowests are the supporting and research indicators. This finding can be followed up by lecturers and stakeholders. Lecturers should actively participate in supporting activities and conduct research utilising current technology. Information obtained through internet media can be utilized, as the media can be used for obtaining reading resources. become participants of seminars, workshops, and become speakers at seminars. This research also supported that, "job performance is defined as the total expedited value to the organization of the discrete behavioural episodes that an individual carries out over a standard period of time" [14]. This means performance is defined as the total value expected for the organization from episodes of discrete behaviour carried out by individuals during the standard period of time. Therefore, the important thing is the expected total value in form of the expected results to achieve organizational goals from the contribution of a set of behaviours.

Furthermore, stakeholders should provide facilitation, attention, comfort and improvement of activities related to research and development of scientific work, for example, inviting lecturers to take part in the training of writing research grants, scientific papers indexed by scopus, and reference books, as well as providing information and so on. This is consistent with results of the research, "positive climate-based positive climate influences employees" positive effect, which in turn enhances their in-roles and extra-role performance [15]. Table 3 shows the results of research indicators on pedagogic competence.

Table 3. Indicators of Pedagogic Competence Average Scores

\begin{tabular}{lll}
\hline Indicators & Average & Percentage \\
\hline
\end{tabular}




\begin{tabular}{lll} 
Learning Plans & 3,69 & 24,68 \\
Implementation of the Learning Process & 3,78 & 25,26 \\
Assessment of Processes and Learning Outcomes & 3,74 & 24,97 \\
Utilization of Research Results to Learning Quality & 3,76 & 25,09 \\
\hline
\end{tabular}

In the pedagogic competency factor, the highest indicator score is in the implementation of the learning process, while the lowest is the learning plan. Follow-ups can be done through the digital era of lecturers to utilize technology in the form of applications, or searching through the internet for content that may help in the designing of Semester Learning Plans (RPS). This is required because it is one of the factors that influence performance. In accordance with the results, pedagogic, professional, social, and personality competencies have significant effects on the dependent variable of lecturer performance [16]. And it supports the opinion that, "Pedagogical competence is about the ability to reflect upon external contexts that constitute the framework for health education [17]. "Pedagogical competence can be described as the ability and willingness to apply the knowledge and skills that promote learning among students" [18]. Therefore, it can be described as the ability and willingness to regularly apply attitudes, knowledge and skills by teachers to enhance learning among students. Pedagogical competencies include the clarification of values. Value clarification challenges health educators to conceptualise their knowledge, norms and understanding, and define what health means to people [17]. Furthermore, it is the ability of an individual to use a combination of real resources that are coordinated and synergistic to attain efficiency and/or effectiveness in pedagogy [19]. So all the capabilities possessed are synergistically coordinated in applying pedagogy in order to attain efficiency. Table 4 explains the indicators affecting work motivation.

Table 4. Average Work Motivation Indicator Scores

\begin{tabular}{lll}
\hline Indicators & Average & Percentage \\
\hline Expectations: expectations can complete the work & 3,83 & 32,04 \\
Instrumentality: confidence in performance gets rewarded & 4,16 & 34,80 \\
Valence: the desired value of the results achieved & 3,97 & 33,16 \\
\hline
\end{tabular}

The highest indicator on work motivation factors is instrumentality, while the lowest is expectations. The follow-up of this research is the need for encouragement to increase selfconfidence, attempt, and daring to take on the challenges that exist today, especially in the digital era. Self-confidence can be developed by attempting challenging tasks. This is required because according to findings, it is one of the determining factors of performance [20]. This means motivation is an internal process that brings about the behaviour required to meet needs. "It refers to the impulse in someone who influences its direction, intensity, perseverance and voluntary behaviour" [21]. Table 5 explains the indicators affecting job satisfaction.

Table 5. Average Job Satisfaction Indicator Scores

\begin{tabular}{lll}
\hline Indicators & Average & Percentage \\
\hline
\end{tabular}




\begin{tabular}{lll} 
Salary & 4,08 & 22,31 \\
Promotions & 3,63 & 19,85 \\
Supervision & 3,51 & 19,21 \\
Coworkers & 3,59 & 19,64 \\
Work Itself & 3,47 & 18,99 \\
\hline
\end{tabular}

On job satisfaction factors, the highest indicator is salary, while the lowest is work itself. The follow-up of this research is the need to increase the feeling related to work in order to stimulate innovative ideas or the creativity in solving problems and developing self-abilities. This is also required because it is one of the determining factors of performance. In accordance with the results, job satisfaction affects performance [22]. Therefore, in order to improve performance, job satisfaction must be improved with site strength moderator variables [23].

\section{Conclusions}

Based on the results of data analysis, it can be concluded that the factors that influence lecturer performance are pedagogic competence, work motivation, and job satisfaction. Furthermore, the factor that should be considered first is the work motivation factor, then job satisfaction, and pedagogic competence. Media in the era of today's technology can be used in improving indicators that influence performance.

\section{References}

[1] Misdalina, "Discruption dalam Pembelajaran Matematika," in Prosiding Seminar Nasional 21 Universitas PGRI Palembang, Palembang, 2018, pp. 482-485.

[2] Misdalina, M. Asmawi, and B. Sujanto, "Analysis of Lecturers' Work Performance Based on Pedagogy Competence and Work Motivation,” Int. J. Sci. Res. Manag., vol. 6, no. 08, Aug (2018.)

[3] J. Colquitt, J. A. Lepine, M. J. Wesson, and I. R. Gellatly, Organizational behavior: Improving performance and commitment in the workplace. McGraw-Hill Irwin (2011)

[4] E. Edison, Y. Anwar, and I. Komariyah, "Manajemen Sumber Daya Manusia: Strategi dan perubahan dalam rangka meningkatkan kinerja pegawai dan organisasi," Bdg. Alf. (2016)

[5] M. Zainuddin et al., Pedoman Sertifikasi Pendidik untuk Dosen Terintegrasi: Buku 1 Naskah Akademik. Jakarta: Ditjen PT Kemendikbud (2014)

[6] Kreitner and Kinicki, "Perilaku Organisasi," Terjem. Landung Jkt. Salemba Empat (2005)

[7] C. A. Wong and H. K. Laschinger, "Authentic leadership, performance, and job satisfaction: the mediating role of empowerment," J. Adv. Nurs., vol. 69, no. 4, pp. 947-959 (2013)

[8] J. König and M. Rothland, "Motivations for choosing teaching as a career: Effects on general pedagogical knowledge during initial teacher education," Asia-Pac. J. Teach. Educ., vol. 40, no. 3, pp. 289-315 (2012)

[9] J. Kowal and N. Roztocki, "Job satisfaction of IT professionals in Poland: does business competence matter?," J. Bus. Econ. Manag., vol. 16, no. 5, pp. 995-1012 (2015)

[10] Misdalina, "Data sets: Pedagogic Competence, Work Motivation, and Job Satisfaction (Factors Influence Lecturer Performance).” 2019. Available: osf.io/7ja2q 
[11] S. Haryono and Y. Arafat, "Effects of Organizational Culture and Work Motivation on Job Performance Among the Private Universities'full-Time Faculties in South Sumatera Province," (2017)

[12] S. Rahardjo, "The effect of competence, leadership and work environment towards motivation and its impact on the performance of teacher of elementary school in Surakarta city, Central Java, Indonesia," Int. J. Adv. Res. Manag. Soc. Sci., vol. 3, no. 6, pp. 59-74 (2014)

[13] J. Gibson, J. M. Ivancevich, and R. Konopaske, Organizations: Behavior, Structure, Processes, 14th ed. The McGraw-Hill Companies, Inc (2012)

[14] S. J. Motowidlo and H. J. Kell, "Job Performance," in Handbook of Psychology, Industrial and Organizational Psychology, Wiley Online Library (2003)

[15] M. Van Woerkom and M. C. Meyers, "My Strengths Count! Effects of a Strengths-Based Psychological Climate on Positive Affect and Job Performance," Hum. Resour. Manage., vol. 54, no. 1, pp. 81-103 (2015)

[16] M. Djasuli, "Studi Eksplanatoris Kompetensi Dosen Ekonomi Terhadap Kinerja Dosen Fakultas Ekonomi di Universitas Trunojoyo Madura," Pamator J., vol. 8, no. 2, pp. 147-154, 2015.

[17] K. Wistoft, "Pedagogical competence and value clarification among health educators," Glob. Health Promot., vol. 16, no. 3, pp. 24-34 (2009)

[18] Å. Ryegård, K. Apelgren, and T. Olsson, A Swedish perspective on pedagogical competence. Division for development of teaching and learning (2010)

[19] S. Madhavaram and D. A. Laverie, "Developing Pedagogical Competence: Issues and Implications for Marketing Education,” J. Mark. Educ., vol. 32, no. 2, pp. 197-213, Aug (2010)

[20] D. S. K. Tobing and M. Syaiful, "The Influence Of Transformational Leadership And Organizational Culture On Work Motivation And Employee Performance At The State Property Service Office And Auction In East Java Province," (2018)

[21] M. A. V. Glinow and S. L. McShare, Organizational Behavior, Emerging Knowledge and Practice for Real World. McGraw. Hill, International Edition. Singapore (2010)

[22] C. Platis, P. Reklitis, and S. Zimeras, "Relation between Job Satisfaction and Job Performance in Healthcare Services," Procedia - Soc. Behav. Sci., vol. 175, pp. 480-487, Feb (2015)

[23] N. A. Bowling, S. Khazon, R. D. Meyer, and C. J. Burrus, "Situational Strength as a Moderator of the Relationship Between Job Satisfaction and Job Performance: A Meta-Analytic Examination," J. Bus. Psychol., vol. 30, no. 1, pp. 89-104 (2015) 